Anna KARCZEWSKA, Magdalena BSOUL

\title{
2.4. PUBLIC RELATIONS IN THE MANAGEMENT OF A MODERN ENTERPRISE - SOLUTIONS FOR CRISIS SITUATIONS
}

\begin{abstract}
Summary
Public relations and communications management covers wide range of ideas such as media relations, public affairs, community affairs, product publicity, events management, crisis management, lobbing, investor relations etc. The article presents an overview of modern aspects of public relations, its role in management of an enterprise, including crisis management. The perception of public management and its roles are changing. The enterprises face the challenges such as fast technological changes, developing of international relations and growing global competition. What is also changing is the nature and tools of communication, what influences the public relations management. Public relations may be a strategic resource which, when appropriately managed, may contribute to effective realization of the strategy of an enterprise. Modern public relations help to understand the environment of an organization and maintain the relations with groups significant to achieving the strategic goals of an enterprise. What is also important issue for modern public relations is an ethical approach to business, social, and environmental responsibility. The authors of the article mention the main characteristics and challenges of modern public relations and try to highlight its significance to the successful operation of an enterprise.
\end{abstract}

Keywords: public relations, management, communications, enterprise

\section{Public relations - a form of communication in an organization}

Every manager of a modern enterprise should be aware of the significance of a communications management for the activity and competitiveness of his organization. Communication processes are crucial to effective functioning of organizations. They influence the realization of the following functions in managing an organization: planning, organizing, motivating and controlling (Stankiewicz, 1998). Good company management requires highly developed communication skills, both on the individual as well as on the organizational level. One of the most important form of company's communication processes is public relations (ed. Heath, 2005).

There are a large number of definitions of public relation. The Encyclopaedia of Public Relations offers a general description of the term: "public relations is a set of management, supervisory, and technical functions that foster an organization's ability to strategically listen to, appreciate, and respond to those persons whose mutually beneficial relationships with the organization are necessary if it is to achieve its mission and vision" (Kunczik, 1993).

One can distinguish also two general ways of defining PR. It refers to the process of shaping mutual relationship between people in various social situations especially in the political, social and economic life and what is more, it refers to the set of actions of the interdisciplinary, knowledge-requiring nature and covering a number of areas, such as media-relations, strategy counselling, crisis and image management etc. (Bsoul, 2010). It can be divided into internal public relations (the public are the members of an 
organization) and external public relations (the public are various stakeholders outside an organization) (Bsoul, 2005).

It may also be defined as a management communication function, which enables a company to "adopt to the environment, changing the environment or maintaining the status quo, providing that the aims of an organization are reached" (Goban-Klas, 1997). Treating Public Management as a form of communication, one can enumerate its main communication functions: selection of information, presentation of information, performing a role of a mediator, being a leader of public opinion (GobanKlas, Kadracic and Czarnowski, 1997).

The conceptualization of the term public relations often perceive it as a continuous activity connected with an organization's relations with the public: "public relations is a planned, continuous activity, conducted with taking into consideration the results of actions. It means conveying by the company specially prepared various forms of information in order to create its desirable image in the environment of the company, which enables better integration with the environment and facilitates the realization of the main goals of a company. This activity may be conducted by other organizations, including profit-oriented" (Heath, 2005).

Before the $20^{\text {th }}$ century, there were several specializations which later evolved into a structured phenomenon of public relations. These specializations now are treated as functions of the public management. Each public management function is characterized by special set of objectives; they aim at building and maintaining as well as fixing relations with various audiences. The most typical specializations and also functions are: corporate communication, media relations, investor relations, community relations, issues management, employee relations, donor relations, government relations and strategic philanthropy (ed. Heath, 2005). Every function of public management is a form of a dialogue with public, so it has to take into consideration the feedback from the public and be prepared for the cooperation with many - stakeholders.

\section{Public relations - a search for the dialogue with the audiences}

The communication form such as public relations has many different audiences and consequently it is not simple and uniform but complex and diverse. It have to justify organization's activity to not only to internal shareholders, but also to customers, public opinion, government, employees, financial groups and media. The form and content of the message should be adopted to the particular environment. Public relations program, which aims at engaging in the dialogue with different public, should take into consideration and analyse the stakeholder specificity. The goals and obligations in public relations depend on the kind of stakeholders it turns to. Table 1 presents main responsibilities of public management directed to different audiences. 
Table 1: Stakeholders' responsibilities

\begin{tabular}{|c|c|c|}
\hline Stakeholder & & Responsibilities \\
\hline \multirow{3}{*}{ Customers } & Economic issues & $\begin{array}{l}\text { Profitability, competitive products, survival of the } \\
\text { company, product quality }\end{array}$ \\
\hline & Ethical issues & $\begin{array}{l}\text { Honesty, the best possible products and services, } \\
\text { satisfy customer needs }\end{array}$ \\
\hline & Voluntary issues & Long-term business, function development \\
\hline \multirow{4}{*}{ Employees } & Economic issues & Work and income \\
\hline & Legal issues & $\begin{array}{l}\text { Cooperation, following the regulations in dismissal } \\
\text { situations }\end{array}$ \\
\hline & Ethical issues & $\begin{array}{l}\text { Good working conditions, stability and security, } \\
\text { developing possibilities, honesty }\end{array}$ \\
\hline & Voluntary issues & Education, supporting activity and interests \\
\hline \multirow[t]{2}{*}{ Competitors } & Ethical issues & $\begin{array}{l}\text { Truthful information, fair marketing and fair pricing } \\
\text { practices, no use of questionable consistency and } \\
\text { stability, playing the game by the rules }\end{array}$ \\
\hline & Voluntary issues & Good relations, cooperation in industry-related issues \\
\hline \multirow[t]{2}{*}{ Owners } & Economic issues & $\begin{array}{l}\text { Return on assets/investments, securing investments, } \\
\text { maximizing cash flow, solvency, profits }\end{array}$ \\
\hline & Ethical issues & Adequate information \\
\hline \multirow{3}{*}{ Suppliers } & Economic issues & Volumes profitability \\
\hline & Ethical issues & Honesty \\
\hline & Voluntary issues & Sustainable and reliable long-term relations \\
\hline \multirow{4}{*}{ Community } & Economic issues & Taxes employment, influence on trade balance \\
\hline & Legal issues & Following laws and regulations \\
\hline & Ethical issues & Behaving with integrity \\
\hline & Voluntary issues & Supporting local activities \\
\hline \multirow{4}{*}{ Government } & Economic issues & Taxes employment, influence on trade balance \\
\hline & Legal issues & Following laws and regulations \\
\hline & Ethical issues & Behaving with integrity \\
\hline & Voluntary issues & Supporting local activities \\
\hline \multirow{2}{*}{$\begin{array}{l}\text { Financial } \\
\text { groups }\end{array}$} & Economic issues & Profitability, security of investment \\
\hline & Ethical issues & Adequate information \\
\hline \multirow{3}{*}{$\begin{array}{l}\text { The } \\
\text { environment } \\
\text { (e.g. pressure } \\
\text { groups) }\end{array}$} & Legal issues & Compliance with environmental regulations \\
\hline & Ethical issues & $\begin{array}{l}\text { Environmental friendliness, protecting the } \\
\text { environment, product recycling }\end{array}$ \\
\hline & Voluntary issues & Proactive environmental management \\
\hline \multirow{3}{*}{$\begin{array}{l}\text { Old and new } \\
\text { media, e.g. } \\
\text { press, TV, } \\
\text { web }\end{array}$} & Legal issues & Compliance with the law \\
\hline & General issues & $\begin{array}{l}\text { Compliance with guidelines, codes of conduct and } \\
\text { ethics statement }\end{array}$ \\
\hline & Voluntary issues & Internal web pages and chat rooms \\
\hline
\end{tabular}

Source: Olivier (2010), pp 17-18. 
The second important element of public relations activity is planning. The planning process is complex and based on the following key issues. The essential aspects are determined by the answers to six main questions, which the public relations managers are obliged to find the answers:

- "What is the problem? (researching the issue)

- What does the plan seek to achieve? (what are the objectives)

- Who should be talked to? (with which publics should a relationship be developed)

- What should be said? (what is the content or message)

- How should the message be communicated? (what channels should be used for dissemination)

- How should success to be judged? (how will the work be evaluated against the objectives)" (Tench and Yeomans, 2006).

In our modern globalized world, it is crucial to adapt the public relations to the requirements of an international publics. The creation of public relations management strategy in the international dimension should take into account:

1. optimizing communication forms on the international market (choice of the most suitable set of promotion tools),

2. optimizing the message (the possible best preparation of a message through the identification of a culture of an audience in a given country),

3. optimizing the attractiveness of a product (a company is required to upgrade the product, increase its desirability taking into account the values and criteria in a given country),

4. optimizing the personnel qualification in particular branch offices (constant improving of personnel's skills, including the language skills)

5. optimizing the flexibility of actions and adapting to the changing environment (making fast changes of marketing program to adapt to changing conditions) (Witek and Adamczyk 2008).

The main aim of public relations activity is to create and maintain the organization's image and reputation and the favour of the environment as well as informing the public of an organization about its activity. What is more, the public relations management influences the attitudes of an organization and its public, monitor and provide the information about changes in the environment and inform the employees about the situation of the organization. One of the most important aims of the public relations is warning about and solving the problems and crisis situations (Smektała 2005).

Depending on what kind of situation public relations manager deals with, he has got the choice of numerous tools of communication and activities available. The collection of the public management activities is presented in Table 2 .

As it emerges from the analysis of the above table, the public relations activities are very diverse - from media relations, customer and community relations to internal communication with the organization's employees and essential, crisis management.

As it was mentioned before, there are different aims connected with different public and it is important to remember about the stakeholder specificity while choosing the best activity in a given situation. 
Table 2: Public relations' activities

\begin{tabular}{|c|c|}
\hline Media relations & Conferences \\
\hline \multirow{9}{*}{$\begin{array}{l}\text { Press conference } \\
\text { Press release } \\
\text { Articles and features } \\
\text { One-to-one briefings } \\
\text { Interviews } \\
\text { Background briefings/materials } \\
\text { Photography } \\
\text { Video news releases } \\
\text { Website, Email }\end{array}$} & Multimedia \\
\hline & Literature \\
\hline & Hospitality \\
\hline & Community relations \\
\hline & Direct involvement \\
\hline & Gifts in kind \\
\hline & Sponsorship \\
\hline & Donations \\
\hline & \multirow{4}{*}{$\begin{array}{l}\text { Special events } \\
\text { AGMs } \\
\text { SGMs } \\
\text { Special occasions }\end{array}$} \\
\hline Advertising (PR led) & \\
\hline Corporate & \\
\hline Product & \\
\hline Direct mail (PR led) & \multirow{10}{*}{$\begin{array}{l}\text { Customer relations } \\
\text { Media relations } \\
\text { Direct mail } \\
\text { Advertising } \\
\text { Internet } \\
\text { Exhibitions } \\
\text { Retail outlets } \\
\text { Sponsorship } \\
\text { Product literature } \\
\text { Newsletter }\end{array}$} \\
\hline Annual report & \\
\hline Brochures/leaflets & \\
\hline Customer reports & \\
\hline External newsletters & \\
\hline General literature (also multimedia material) & \\
\hline Exhibitions & \\
\hline Trade and public & \\
\hline Literature & \\
\hline Sampling & \\
\hline $\begin{array}{l}\text { Demonstrations } \\
\text { Multimedia }\end{array}$ & \multirow{7}{*}{$\begin{array}{l}\text { Internal communication } \\
\text { Videos } \\
\text { Briefings } \\
\text { Newsletters } \\
\text { Quality guides } \\
\text { Compact disk interactive } \\
\text { Email } \\
\text { Intranet }\end{array}$} \\
\hline Lobbying & \\
\hline One-to-one briefings & \\
\hline Background material & \\
\hline Videos, Literature & \\
\hline Group briefings & \\
\hline Hospitality & \\
\hline CDs, Audio cassettes & \multirow{3}{*}{$\begin{array}{l}\text { Corporate identity } \\
\text { Design } \\
\text { Implementation } \\
\end{array}$} \\
\hline Research & \\
\hline Organisations & \\
\hline Public relations programmes & \multirow{4}{*}{$\begin{array}{l}\text { Sponsorship } \\
\text { Sport } \\
\text { Arts } \\
\text { Worthy causes }\end{array}$} \\
\hline Issues monitoring & \\
\hline Results monitoring & \\
\hline Crisis management & \\
\hline $\begin{array}{l}\text { Planning } \\
\text { Implementation }\end{array}$ & \multirow{2}{*}{$\begin{array}{l}\text { Financial relations } \\
\text { Annual report } \\
\text { Briefing materials, One-to-one briefing } \\
\text { Media relations } \\
\text { Hospitality } \\
\text { Internet } \\
\text { Extranet }\end{array}$} \\
\hline $\begin{array}{l}\text { Liaison } \\
\text { Internal (including counseling) } \\
\text { External } \\
\text { Implementation }\end{array}$ & \\
\hline
\end{tabular}

Source: Tench and Yeomans (2006), p. 198. 


\section{Public relations - solutions for the crisis}

Public relations activity is particularly significant during the crisis situations. We may define a situation of crisis as: "usually sudden and unexpected, undesirable event, destabilizing the balance of a company and being a threat for a certain field of its activity" (Smektała, 2005). Mitroff enumerates the most frequent types of crisis segregated according to the source of the problem:

1. External economic problems (bribery, boycott, extortion, acquisition of assets (also against the will of the owner)

2. External informational problems (loss of data, forgery false rumours personal data breach)

3. Professional factors (health and diseases)

4. Breaks in work (removal from a post, failures, product defects, errors of operators, low level of safety)

5. Human resources (low morale, takeover of the executive power by the successor)

6. Visible damage (false rumours, slander, calumny)

7. Damage on a large scale (accidents, damage to the environment)

8. Psychopathology (illegal copying, tampering within the company and outside the company, sexual harassment, false rumours, hijacking high official) (Smektała, 2005).

A crisis lasts some time, develop and goes through several steps. Fink presents a lifecycle of a crisis composed of four steps: "prodromal, where warning signs appear before a crisis hits; crisis breakout or acute, where the trigger event occurs or what we typically think of as the crisis happening; chronic, the time it takes to attend to the damage and disruption from the crisis; and finally resolution, in which there is evidence that the crisis is over and no longer a factor with stakeholders" (in Heath, 2005, p. 216).

Due to the development of new information and communication technologies and the fast flow of information in the Internet websites, the speed of people's communications increased rapidly.

The company, which aims at being competitive on the market and deal with the potential crises, should react as quickly as possible and use the tools which the Internet provides for the initial response to the crisis. And what is important is to prevent and plan ahead to be prepared for the potential problems.

What is more, the powerful role of media in modern public communication makes the relationships with media very important for the companies. There is a shift towards more open and communicative relationships with the media environment. It has a great influence on corporate image and enables contact with the wide range of audiences (White and Mazur 1998).

Crisis management aims not only at reacting to a crisis. Proactive crisis management attempts to prevent the crisis, fight with it and lessen the possible and actual damage the crisis had caused. It may be divided into four steps: prevention, preparation, response and learning. So it is not only having a plan for crisis, yet planning is the essential element of crisis management. It is important to exercise the plan, prepare the crisis management team to its realization. It is advisable for the crisis management 
team to consist of people who respond to the crisis. It is recommended for the team to be cross-functional, which means that it gathers people from different parts of the organization in order to have various skills and knowledge in the team. Crisis team may include the following membership: operations, legal, public relations, security, facilities management (White and Mazur 1998).

Prevention of the problems and crises conducted by the management should include:

- making aware of the potential for crisis in the organization,

- organization of crisis team and training of the team members,

- preparing the emergency plan,

- preparing the supply base,

- preparing the documentation of previous crisis situations,

- observation of the competitors (Mruk 2002).

According to Simon and Zapala, the effective dealing with crisis situations requires adopting the following features of activity:

- factual view of the problems,

- proper strategy of activity and mobilization of supporting groups,

- presenting engagement and compassion of a company towards the injured party,

- carrying out symbolic actions (declaring help, showing goodwill),

- establishing the direct contact with the injured,

- showing the possibilities of getting a compensation,

- declaring to take instant actions towards liquidation of effects of the event, possibly also concrete prevention solutions for the future,

- having open and factual policy of communication together with the use of emotional arguments (Simon and Zapala 1996).

However, companies adopt several strategies in practice. It may be admitting to guilt and cooperation with the public, as recommended above. Presently one can often find strategies of keeping silence and ignoring the situation or even attacking and opposing to the allegations. Still active and factual informing the public in the situation of crisis prevent more conflicts from occurring and is more beneficial for the company's image and reputation.

\section{Conclusion}

Modern enterprises have to combine economic issues with ethical issues and build relationships with many different audiences. Good use of communication is essential for obtaining a company's strategic objectives. Global business environment, technological changes demand from companies to operate responsibly, maintain relationships with public and react to the crisis as fast as it is possible.

The good external strategy of communication contributes to an effective activity of a company and to preventing problems from occurring or dealing with them successfully. Internal communication (with employees) helps the members of an organization to be more efficient and effective in service or production.

It is advisable to if not appoint special public relation department or a manager responsible for the public relations, then to use the services of a public relations consultancy. 
Otherwise, the company may have bad or inconsistent relationships with the environment and miss the opportunities and benefits which result from conducting the effective public relations activity.

\section{References}

1. Bsoul, M. (2005): Public relations, in: Encyklopedia Pedagogiczna XXI w, Vol. IV, Wyd. Akademickie „Żak”, Warszawa, p. 1294

2. Bsoul, M. (2010): Zasady dobrego Public relations w polityce, in: Public relations w procesie kształtowania relacji z otoczeniem, D. Tworzydło, Z Chmielewski(eds), Wyd.Konsorcjum Akademickie,Kraków-Rzeszów-Zamość, p.11.

3. Heath, R. L. (ed.) (2005): Encyclopedia of Public Relations, Sage Publications, p. 680.

4. Tench, R., Yeomans, L. (eds) (2006): Exploring public relations, Pearson Education, pp 186187.

5. Goban-Klas, T., Kadracic, A., Czarnowski, P. (1997): Public relations czyli promocja reputacji: pojęcia, definicje, uwarunkowania, Ed.2, Business Press, Warszawa, after: Smektała T. (2005): Public relations w sytuacjach kryzysowych przedsiębiorstw, Wyd. Astrum, Wrocław, p. 13.

6. Goban-Klas, T. (1997): Teoria komunikowania jako fundament public relations, „Marketing i Rynek", nr 4, p. 7.

7. Kunczik, M. (1993): Public Relations. Konzepte und Theorien, Böhlau Verlag GmbH \& Cie, Köln, p.10.

8. Mruk, H. (ed.) (2002): Komunikowanie się w biznesie, Wyd. AM w Poznaniu, Poznań, p 139.

9. Olivier, S. (2010): Public relations strategy, Kogan Page, London, pp. 17-18.

10. Simon, R., Zapala, J.M. (1996): Public relations workbook, Writing \& techniques, NTC Business Books, Lincolnwood, Illinois, p.214-215, after: Mruk H. (ed.) (2002), Komunikowanie się w biznesie, Wyd. AM w Poznaniu, Poznań, p 142.

11. Smektała, T. (2005): Public relations w sytuacjach kryzysowych przedsiębiorstw, Wyd. Astrum, Wrocław, pp 68-69.

12. Stankiewicz, J. (1998): Komunikowanie się w organizacji, Wyd. PZ, Zielona Góra, p 15.

13. White, J., Mazur, L., (1998): Strategic Communications Management. Making Public Relations Work, Addison-Wesley Publishing Company, pp 125-127.

14. Witek, L., Adamczyk, J. (2008): Marketing międzynarodowy, Oficyna Wydawnicza Politechniki Rzeszowskiej, Rzeszów, p. 12. 